HYGIENE OF THE NEhVOUS SYSTEM.

Why Worry? By Dr. G. L. Walton. Pp. 275. (London: W. Heinemann, I9o9.) Price $2 s .6 d$. net. Self-Holp for Nervous Women: Familiar Talks of Economy in Nervous Expenditure. By Dr. J. K. Mitchell. Pp. 202. (London: IV. Heinemann, I9o9.) Price 2s. 6d. net. $\mathrm{W}$ to attribute to disorder of conduct is, by many, now placed in the category of functional nervous disturbance, and concomitantly it has been sought to relieve judicial and ecclesiastical officers of their duties and to devolve them upon the medical profession. In the two small books under review we find, expressed in popular language, that which amounts to a series of short sermons written by medical men, and for the most part addressed to those who are suffering from the effects of a lack of self-control. For one of our authors it is "not his aim to transform the busy man into a philosopher of the indolent and contemplative type," but to enable him to do his work effectively by eliminating undue solicitude. The other defends himself from the possible criticism that his advice is not new. We cannot suppose any such defence will be necessary. The advice proffered is that of Epictetus, Marcus Aureiius, and Seneca, but stops short, we may presume out of respect for the attitude of current science towards current religion, at the plane of these philosophers.

Dr. Mitchell points out how some of the conspicuous and peculiar virtues of women may become sources of trouble. Strong affections and sympathy are apt to lead to emotional excess, and such excess, whether spent in grief, love, hate, or ambition, is the most extravagant form of nervous expenditure, and may eventuate in bankruptcy. A very frequently predisposing cause of nervousness is the too ready yielding to emotional expression, along with the cultivation of an excessive manifestation of emotion in speech and manner. Many women account it an attraction to give way to tears for trifling pains, or to loud complaints expressed in exaggerated language about small annoyances, and it is pointed out to these that to endure the smaller inevitable woes with equanimity is to form a habit which shall be of immense service when the larger troubles arise.

Much useful advice is given upon those physical causes which tend to develop nervous manifestations, or to exaggerate them when they are already present. On one hand there is a large number of persons who attribute many trifling derangements of various organs to their "nerves," and, on the other hand, there are others who fail to recognise their disorders as being nervous in origin until severe mental symptoms arise, and each class will find the information which may be gathered from these books of great help. Due attention, neither too prolonged nor too scanty, to the hygiene of the nervous system will in the future doubtless go as far as prophylactic hygiene has already gone in connection with the other systems, and it must be recognised that the education of the child is in this connection of paramount importance. Something between Spartan severity and No. 2108 , VOL. $83 j$ the opposite extreme, to which there seems to be a serious danger of our passing, is the educational goal to which we should press, to the development of that degree of self-control which shall avert the nervous weakness which issues in each petty emotion usurping entire control over the body.

For those who are "nervously" disposed we can ask for no better advice than that given in the small volumes before us, and we should certainly feel assured that those who would read the books and would endeavour to act upon the suggestions therein contained were well on the road to recovery. Unfortunately, there is an enormous residue of patients who will listen to no advice, though they pay a man to give it them, and yet another class which, while recognising the advice given to be sound, seems wholly incapable of the amount of self-help requisite to acting upon it.

\section{MYCOLOGICAL WORKS.}

(I) Researches on Fungi. By Prof. A. H. Reginald Buller. Pp. $x i+287$. (London: Longmans, Green and Co., I909.) Price I2s. 6d. net.

(2) Die Wiirzelpilze der Orchideen, ihre Kultur und ihr Leben in der Pflanze. By Dr. Hans Burgeff. $P_{p}$. iv $+220 ; 3$ plates, and $3^{8}$ figs. in text. (Jena: Gustav Fischer, I909.) Price 6.50 marks.

(3) Fungi and How to Know Them: an Introduction to Ficld Mycology. By E. W. Swanton. Pp. xi+2ro. (London: Methuen and Co., rgog.) Price $6 s$. net.

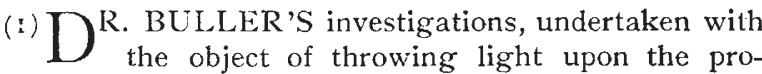
duction, liberation, and dispersion of spores in the group of fungi known as the Hymenomycetes, breaks new ground, and, as usual in such instances, will undoubtedly form the starting point of future research on the part of many students. A brief sketch of the components of a typical hymenium or sporebearing surface are first dealt with. It is pointed out that swollen gill-margins serve to separate the gills, otherwise the spores could not be shed. This may be true in those instances where thickened gill edges exist, but in at least seventy-five per cent. of known agrarics the edge of the gills is not in the least thickened.

Under nuclear phenomena it is pointed out that the passage of the nucleus from the basidium through the very narrow sterigma into the spore affords striking evidence of protoplasmic plasticity. This point has been previously emphasised by Wager. The classification of the Agaricineæ according to spore colour is dubbed as a purely artificial arrangement, but no valid reason for this statement is forthcoming. The author does not appear to realise that what the systematist understands by black spores are spores thrown down in the mass; no spores are black, even under the microscope, but they may be opaque, and consequently appear to be black.

In a work devoted to research it is generally assumed that the author is conversant with what has been done previously on the same subject; this, however, does not hold good in the present instance; for 